\title{
PENGARUH RADIASI SINAR ULTRAVIOLET TIPE C (UVC) TERHADAP KULTUR TOTAL MIKROBA IKAN ASAP PINEKUHE
}

\author{
Effect of Ultraviolet Type C (UVC) Radiation on Microbes Isolated \\ From Pinukuhe Smoked Fish
}

Jaka Frianto Putra Palawe, Jefri Mandeno

Teknologi Pengolahan Hasil Laut, Politeknik Negeri Nusa Utara Email: palawejakafriantoputra@gmail.com

\begin{abstract}
Abstrak : Untuk meningkatkan mutu produk olahan khas daerah, khususnya ikan asap pinekuhe, pengembangan teknik atau instrumen baru menjadi sebuah keharusan. Sejauh ini, metode yang umum digunakan untuk mempertahankan mutu produk pangan, khususnya mutu mikrobiologis, adalah mensterilkan produk pangan untuk mengurangi dan menginaktifkan mikroba kontaminan misalnya melalui perebusan, penggaraman atau pengasapan. Tetapi metode steriliasi menggunakan sinar ultraviolet khususnya tipe C (UVC) belum banyak diterapkan pada produk pangan di Indonesia. Sinar ultraviolet adalah gelombang elektromagnetik yang memiliki muatan elektron berfrekuensi tinggi dan panjang gelombang 100-400 nm. Sinar UV dapat memotong rantai basa nitrogen dalam RNA atau DNA sehingga menyebabkan kegagalan pemberian kode genetik untuk sintesa protein dan kematian mikroba. Penelitian ini bertujuan untuk mempelajari pengaruh sinar UVC terhadap isolat kultur mikroba dari ikan asap pinekuhe dengan menggunakan metode observasi dan analisa data secara deskriptif. Koloni bakteri yang diisolasi dari ikan pinekuhe dipaparkan dengan sinar UVC dengan perlakuan (12, 24, 36 dan 48) jam. Hasil penelitian menunjukan bahwa sinar ultra violet tipe c (UVC) dengan daya 8 va dan penyinaran 48 jam mempengaruhi pertumbuhan koloni mikroba ikan asap pinekuhe secara maksimal berupa kekeringan pada koloni bakteri isolat dari ikan asap pinekuhe.
\end{abstract}

Kata Kunci: Pinekuhe, UVC, Iradiasi, Sterilisasi, Sangihe

\begin{abstract}
To improve quality of pinekuhe smoked fish locally produced in Sangihe Islands, development of new techniques or instruments becomes necessary. Widely used techniques for maintaining food quality mainly include sterilization through boiling, salting or smoking. To date, however, sterilization by ultraviolet type $C(U V C)$ has been poorly practiced for preserving food products in Indonesia. Ultraviolet light is an electromagnetic wave that has a high frequency electron charge with a wavelength of 100-400 nm. It can cut the nitrogenous base chains in RNA or DNA resulting in coding failure in protein synthesis, causing the death of microbes. This research aimed to study the effect of UVC on microbes isolated from pinekuhe. The results showed that UVC radiation with 8 vafor 48 hours significantly affected the growth of microbial colonies isolated from the smoked fish, drying up the bacterial colony.
\end{abstract}

Keyword: Pinekuhe, UVC, Irradiation, Sterilization, Sangihe

\section{PENDAHULUAN}

Ikan asap pinekuhe merupakan produk lokal olahan hasil perikanan yang berasal dari Kepulauan Sangihe. Ikan asap pinekuhe memiliki ciri khas khusus yang membedakan dengan produk ikan asap lainnya, Ciri khas tersebut yaitu dari segi teknik pengolahannya, dimana pada pengolahannya dilakukan teknik pembelahan dan pelipatan yang hanya bisa dilakukan oleh seorang professional atau berpengalaman (Palawe $e t$ al. 2014). Teknik pengolahan ikan asap pinekuhe dilakukan dengan prinsip pengasapan tradisional, oleh karena itu produk akhir dari ikan asap pinekuhe sangat rentan terhadap kontaminasi mikroba. Hasil penelitian menunjukan bahwa ikan asap pinekuhe memiliki nilai total mikroba diatas ambang batas yang ditentukan oleh Standar Nasional Indonesia (SNI) (Palawe et al., 2014). 
Hal ini disebabkan karena kurangnya sanitasi dan hygine pada saat pengolahan. Hal ini diperparah karena tidak adanya pengemasan pada produk akhir dan pada saat pemasaran produk hanya ditempatkan diatas meja dan dibiarkan diruang terbuka pada kondisi lingkungan pasar yang rentan terhadap kontaminasi mikroba. Mengingat pentingnya meningkatkan mutu produk olahan khas daerah, khususnya ikan asap pinekuhe, maka perlu dikembangkan adanya teknik atau instrumen baru dalam mewujudkan tujuan tersebut. Salah satu cara menjaga mutu produk pangan, khususnya mutu mikrobiologis, adalah dengan adanya sterilisasi pada produk pangan untuk mengurangi dan menginaktifkan mikroba yang mengkontaminasi produk tersebut. Salah satu metode sterilisasi modern yang banyak berkembang dalam industri pangan di Indonesia, yaitu sterilisasi dengan metode iradiasi. Sinar ultraviolet merupakan gelombang elektromagnetik yang memiliki muatan elektron dengan frekuensi tinggi dengan panjang gelombang 100-400 nm (Koutchma T, 2014). Sinar ultra violet dapat memotong rantai basa nitrogen pada RNA atau DNA sehingga terjadi kegagalan koding pada sintesis protein, sehingga menyebabkan kematian mikroba atau protozoa. (Koutchma et al., 2009, Hollaender et al,1999). Penggunaa sinar ultraviolet pada bahan pangan telah banyak telah banyak dilakukan penelitian, antara lain; penggunaan sinar ultraviolet sebagai bakterisida untuk daging mentah (Stermer,1987), Penggunaan sinar ultraviolet untuk megurangi bakteri patogen dan bakteri pembusuk pada daging ayam filet (Mcleod, 2017), Dekontaminasi daging paha ayam menggunakan pulsed ultraviolet (Cassar, 2019), penggunaan UV untuk sterilisasi makanan sonde (Sulatri,2017). Pada penelitian ini akan dilakukan penerapan sterilisasi metode sinar UVC pada kultur mikroba isolasi dari ikan asap pinekuhe untuk memperkuat hipotesis pada penerapannya secara langsung pada produk ikan asap pinekuhe. Penelitian sejenis yang sebelumnya yang pernah dilakukan yaitu penerapan UVC untuk membunuh koloni Bacillus $S p$ pada media nutrient agar (Ariadi, 2009). Penelitian ini memiliki tujuan untu mengidentifikasi pengaruh sinar ultra violet terhadap kultur mikroba isolasi dari ikan asap pinekuhe.

\section{METODE PENELITIAN}

\section{Alat dan bahan}

Alat yang digunakan dalam penelitian ini terdiri dari alat untuk kultur mikroba dan alat untuk pembuatan box ultra violet. Alat untuk kultur microbe ialah sebagai berikut; tabung reaksi, cawan petri, pipet, inkubator, laminar air flow, autoclave,dll. Alat untuk meembuat box ultra violet ialah sebagai berikut; lampu ultra violet, kaca cermin, besi siku tipis, gergaji besi, baut dll. Bahan yang digunakan pada penelitian ini yaitu ikan asap pinekuhe dari Pasar Towoe, nutrient agar, lem kaca dll.

\section{Prosedur Penelitian}

Penelitian ini dilakukan dengan tiga tahap. Tahapan penelitian ini ialah sebagai berikut; Tahap pertama pada penelitan ini yaitu pembuatan box oven UVC dengan menggunakan lampu ultraviolet dengan dinding box terbuat dari kaca cermin. Ukuran dari box oven UVC yaitu $40 \mathrm{~cm}^{3}$. Tahap kedua yaitu pengkulturan mikroba ikan asap pinekuhe. Pengkulturan dilakukan dengan cara mengisolasi mikroba dari ikan asap dengan cara mengencerkan sampel ikan asap dengan larutan fisiologis $\mathrm{NaCl} 0.9 \%$ pada pengenceran 10-1 sampai 105 dan ditumbuhkan pada media nutrient agar. Kultur bakteri yang digunakan pada penelitian ini yaitu pada cawan petri yang memiliki Jumlah koloni berkisar 25100 koloni, alasan penggunaan jumlah koloni ini adalah karena jumlah koloni mudah dihitung. Tahap ketiga penelitian ini yaitu dengan menempatkan koloni mikroba 25-100 pada box oven UVC dengan perlakuan lama penyinaran kemudian dilihat hasilnya secara visual.

\section{Rancangan Penelitian}

Penelitian ini dilakukan dengan metode observasi dengan perlakuan radiasi UVC 12 jam, 24 jam, 36 jam dan 48 jam terhadap kenampakan koloni mikroba 
isolasi dari ikan asap pinekuhe yang diinkubasi selama 48 jam pada media nutrient agar.

\section{Analisis Data}

Analisis data pada penelitian ini menggunakan metode deskriptif dengan memaparkan lewat gambar dan diagram.

\section{HASIL DAN PEMBAHASAN}

\section{Instrumen UVC}

Salah satu hasil dari penelitian ini yaitu pembuatan kotak radiasi UVC. Instrumen kotak radiasi sinar UVC dapat dilihat gambar dibawah ini.

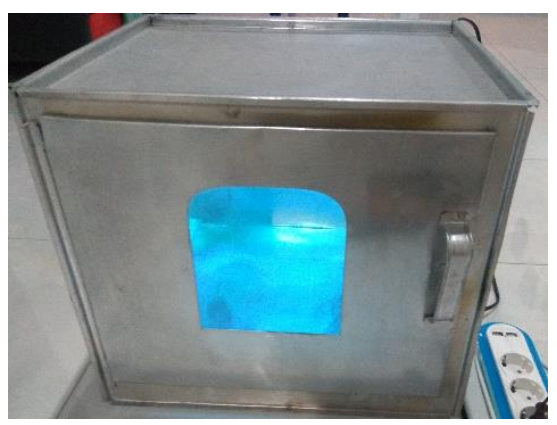

Gambar 1. Oven Radiasi Sinar UVC (modifikasi)

\section{Hasil Penyinaran UVC}

Setelah dilakukan penyinaran dengan sinar UVC didapatkan terjadinya kematian mikroba yang ditandai dengan adanya pengeringan koloni yang tumbuh dalam media agar. Pengeringan terjadi seiring dengan lama pemaparan sinar UVC. Pengeringan koloni mulai terlihat dari waktu 12 jam sampai 48 (gambar 3). Metode perhitungan presentase pengeringan mikroba adalah dengan rumus berikut ini :

$$
\frac{\text { Jumlah Koloni Kering }}{\text { Total koloni Awal }} \text { x 100\% }
$$

Foto koloni sebelum dan sesudah penyinaran UVC serta presentase kekeringan bakteri dapat dilihat pada gamba Gambar 2.

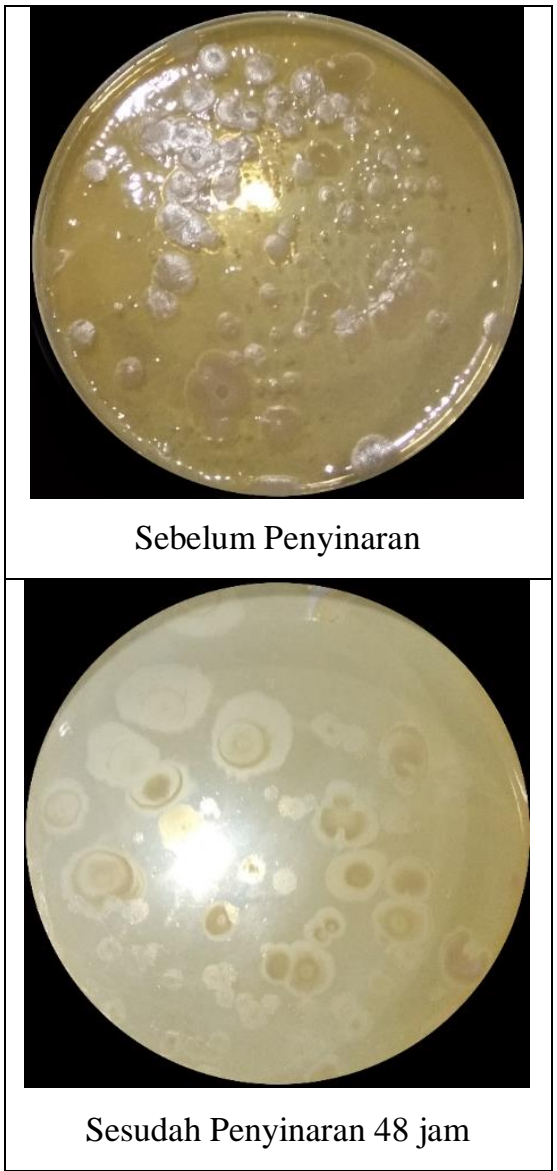

Gambar 2. Koloni Sebelum dan Sesudah Penyinaran UVC

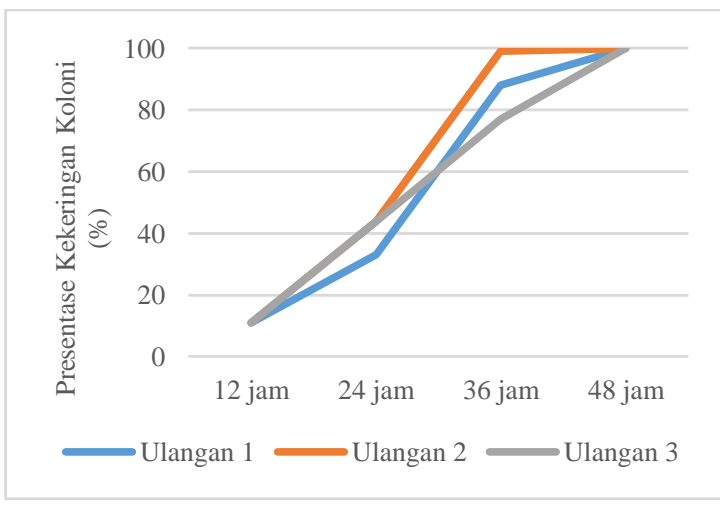

Gambar 3. Presentase Kekeringan Bakteri dengan Tiga Kali Ulangan

Pengaruh penyinaran sinar ultaviolet telah dilakukan pada beberapa produk hasil perikanan seperti menurunkan jumlah koloni E. coli, S. aureus dan B cereus pada produk ikan kulit pasir bumbu kering dan sotong bumbu kering (Eun Seon Lee et al, 2015). Penelitian lain terhadap ikan salmon dan kod, 
menunjukan bahwa UVC berpengaruh terhadap penurunan jumlah Salmonella, E. coli, bakteri enterokoki dan spora Clostridium sporogenes (Skowron et al, 2014). Sinar ultraviolet merupakan gelombang elektromagnetik yang memiliki muatan elektron dengan frekuensi tinggi dengan panjang gelombang 100-400 nm (Koutchma T, 2014). Sinar ultra violet dapat memotong rantai basa nitrogen pada RNA atau DNA sehingga terjadi kegagalan koding pada sintesis protein, sehingga menyebabkan kematian mikroba atau protozoa. (Koutchma et al., 2009, Hollaender et al,1999).

\section{KESIMPULAN}

\section{Kesimpulan}

Dari hasil penelitian ini dapat disimpulkan bahwa sinar ultra violet tipe c (UVC) dengan daya 8 va dapat mempengaruhi pertumbuhan koloni mikroba yang diisolasi dari ikan asap pinekuhe. Pengaruh tersebut dapat dilihat dengan adanya perubahan koloni menjadi kering. Perubahan tersebut terjadi secara maksimal pada penyinaran dengan waktu 48 jam.

\section{DAFTAR PUSTAKA}

Cassar, JR., Edward, WM., Jonathan, AC., Demirci, A. 2019. Decontamination of Chicken Thigh Meat by Pulsed Ultraviolet Light. Meat and Muscle Biology 3(1):479-487. The Pennsylvania State University. doi:10.22175/mmb2019.08.0033.

Hollaender, A. 1995. Radiation Biology.Vol.II. Effects of Radiation on Bakteria. Cornelli.Itacha N.Y.

Koutchma, T. 2014. Introduction. In Food Plant Safety (p. 1). Elsevier. https://doi.org/10.1016/B978-012-416620-2.00001-1

Koutchma, TN., Forney, LJ., Moraru, CI. 2009.

Ultraviolet light in food technology: Principles and applications. CRC Press.

McLeod A., Kristian HL., John-Erik Haugen, Oddvin Sørheim, Kristine S. Myhrer, Askild L. Holck.
2017. Chicken fillets subjected to UV-C and pulsed UV light: Reduction of pathogenic and spoilage bacteria, and changes in sensory quality.Jornal Of Food Safety.Wiley. Nofima, Norwegian Institute of Food, Fisheries and Aquaculture Research, Ås, Norway. DOI: $10.1111 /$ jfs. 12421

Mandeno, J. A dan Kaim M.A, 2015. Pengaruh Pengemasan Terhadap Mutu Pinekuhe Ikan Layang (Decapterus sp) Asap. Jurnal ilmiah Tindalung Volume 1 Nomor 1 Halaman 7-11, Tahuna

Palawe, JFP., Suwetja, IK., Mandey, LC. 2014. Karakteristik Mutu Mikrobiologis Ikan Pinekuhe Kabupaten Kepulauan Sangihe. Jurnal Ilmu dan Teknologi Pangan. Pasca Sarjana Universitas Sam Ratulangi. Manado

Shama, G.Ultraviolet Light. In R. L. Robinson, C. Batt and P. Patel (eds). 1999. Encyclopedia of Food (pp.2208). London: Academic Press.

Skowron K, Bauza-Kaszewska J, DobrzaNski Z, Zbigniew P, and Karolina JS. 2014. UV-C Radiation as a Factor Reducing Microbiological Contamination of Fish Meal. Hindawi Publishing Corporation. The Scientific World Journal. Volume 2014. http://dx.doi.org/10.1155/2014/928094

Stermer Raymond A, Margaret Lasater-Smith and Clayton F. Brasington1987.Ultraviolet Radiation-An Effective Bactericide For Fresh Meat. Journal of Food Protection, Vol. 50, No. 2, Pages 108-111. U.S. Department of Agriculture. Texas A\&M University

Sulatri Ni Luh, Ida Bagus Agung Yogeswara, Ni Wayan Nursini.2017. Efektifitas sinar ultraviolet terhadap cemaran bakteri patogen pada makanan cair sonde untuk pasien immunecompremissed. Jurnal Gizi Indonesia, 5 (2), 2017: 112-118 